\title{
Rupture of hepatic artery aneurysm associated with ischemic hepatitis
}

\section{Rotura de arteria hepática aneurismática asociada con hepatitis isquémica}

\author{
V.M. Santos ${ }^{1,2}$, R.B. Villaça ${ }^{3}$, A.C.A. Almeida ${ }^{2}$, E.R.N.C. Oliveira ${ }^{2}$, P.R.M. Nogueira Junior ${ }^{2}$, \\ E.A.M. Damasceno ${ }^{4}$
}

\begin{abstract}
Hepatic artery aneurysms are scarcely reported, mainly because of non-specific symptoms. More often, they are incidental findings during imaging studies to investigate other acute or chronic abdominal conditions. These aneurysms are usually detected in the sixth decade of life, predominantly among males.

We report the case of a 69 year-old female with an unsuspected huge hepatic artery aneurysm associated with ischemic hepatitis. Suspicion of aneurysm arose during imaging studies to clarify the origin of jaundice and abdominal pain. After establishment of the diagnosis, but before open surgery, there was a spontaneous rupture of the aneurysm, which caused hemoperitoneum and death. The necropsy study confirmed ischemic hepatitis.
\end{abstract}

Hepatic artery aneurysms are second among the visceral aneurysms, and may cause abdominal pain, jaundice, and hemorrhagic events.

One should suspect abdominal aneurysms in elderly patients with unclear abdominal pain, and this hypothesis should be ruled out by imaging studies.

Key words. Aneurysmal rupture. Hepatic artery. Hemoperitoneum. Ischemic hepatitis

\section{RESUMEN}

La publicación de trabajos sobre aneurismas en la arteria hepática es escasa, debido a los síntomas no específicos y a que constituyen hallazgos incidentales durante investigación de otras condiciones abdominales agudas o crónicas. Estos aneurismas son más frecuentes en varones y en la sexta década de la vida.

Presentamos el caso de una mujer de 69 años de edad que ingresa en el hospital con un aneurisma de arteria hepática no sospechado previamente, asociado con hepatitis isquémica. La sospecha de aneurisma empezó durante estudio de imágenes para aclaramiento del origen de ictericia y dolor abdominal. Después de confirmado el diagnóstico, pero antes de la operación planeada, ocurrió rotura espontánea del aneurisma causando hemoperitoneo y muerte. El estudio de necropsia confirmó hepatitis isquémica.

Los aneurismas de la arteria hepática son los segundos entre los aneurismas viscerales y pueden causar dolor abdominal, ictericia y eventos hemorrágicos. Debemos sospechar de aneurisma visceral en ancianos con dolor abdominal no aclarada, posibilidad que debe ser descartada por estudios de imágenes.

Palabras clave. Rotura aneurismática. Arteria hepática. Hemoperitoneo. Hepatitis isquémica
1. Catholic University Medical Course

2. Department of Internal Medicine from Armed Forces Hospital. Brasília-DF. Brazil

3. Department of Gastroenterology from HFA

4. Department of Pathology from North Wing Regional Hospital. Brasília-DF. Brazil

\section{Correspondencia}

Dr. Vitorino Modesto dos Santos

SMPW Quadra 14, conjunto 2, lote 7, casa A

Setor de Mansões Park Way, 71745-140

Brasília-DF. Brazil

E-mail: vitorinomodesto@gmail.com

Recepción el 18 de enero de 2010

Aceptación provisional el 1 de febrero de 2010

Aceptación definitiva el 20 de mayo de 2010 


\section{INTRODUCTION}

Aneurysms of hepatic artery are considered rare, and rupture of true aneurysms has been scarcely described ${ }^{1-4}$. The incidence of hepatic aneurysms varies between $0.01-0.2 \%^{1-3}$, and main predisposing factors include atherosclerosis, arterial hypertension, and infections $\mathbf{s}^{1,2}$. This condition can be mistaken by visceral pseudoaneurysms, usually related with trauma or infection, and may constitute a diagnosis challenge with commoner causes of abdominal pain and jaundice. More often, visceral aneurysms are incidentally found during imaging studies of those entities. Worth of note, hepatic artery aneurysms are the second among the visceral aneurysms, and may cause hemorrhagic events. Spontaneous rupture of aneurysms is a potential cause of hemoperitoneum ${ }^{1-3}$, which may occur in $14-85 \%$ of the hepatic artery aneurysms, with mortality taxes ranging from $35 \%$ up to $85 \%{ }^{1-3}$. The purpose of this report is to emphasize the role of abdominal imaging studies to promptly characterize the correct diagnosis ${ }^{4}$, contributing to successful treatment of the aneurysm before occurrence of spontaneous rupture. Additionally, the association of ruptured aneurysm with ischemic hepatitis is described.

\section{CASE REPORT}

A 69 year-old female with antecedent of arterial hypertension was admitted presenting with loss of appetite, nausea, vomiting, and rigors for a week. She denied antecedent of abdominal trauma or tuberculosis. Admission examination was unremarkable, except for light jaundice and pain provoked by palpation of the right hypochondrium area. Laboratory data during hospitalization are showed in table 1.

Table 1. Laboratory data of a 69-year-old woman with giant hepatic artery aneurysm and ischemic hepatitis.

\begin{tabular}{l|c|c|c}
\hline Parameters / Days of admission & Day $\mathbf{1}$ & \multicolumn{1}{c}{ Day $\mathbf{6}$} & Day 10 \\
\hline Red cells (x 10'1/L) & 4.81 & $\mathbf{3 . 4 2}$ & $\mathbf{3 . 3 3}$ \\
Hemoglobin (g/L) & 14.6 & $\mathbf{1 1 . 2}$ & $\mathbf{1 0 . 9}$ \\
Hematocrit (\%) & 46.1 & $\mathbf{3 2 . 9}$ & $\mathbf{3 2 . 1}$ \\
White blood cells (x 109/L) & $\mathbf{1 3 . 3}$ & 9.7 & 10.4 \\
Platelets (x 10//L) & 197 & 180 & 286 \\
Glucose (mg/dL) & 87 & 91 & 84 \\
Urea (mg/dL) & $\mathbf{5 0 . 1}$ & 19.3 & 21.7 \\
Creatinine (mg/dL) & $\mathbf{1 . 3}$ & 0.6 & 0.5 \\
AST (U/L) & $\mathbf{2 , 3 9 2}$ & 17.4 & $\mathbf{5 2 . 7}$ \\
ALT (U/L) & $\mathbf{2 , 7 9 7}$ & 18.0 & $\mathbf{1 3 9 . 0}$ \\
GGT (U/L) & 30.0 & 30.0 & $\mathbf{5 3 . 7}$ \\
Alkaline phosphatase (U/L) & 68.8 & 52.6 & 135.1 \\
Total bilirubin (mg/dL) & $\mathbf{3 . 0}$ & $\mathbf{2 . 7}$ & $\mathbf{1 . 7}$ \\
Prothrombin time & Prolonged & Prolonged & Prolonged \\
\hline
\end{tabular}

Abnormal data are showed in bold.

Tests for viral hepatitis and HIV infection were negative. Levels of CEA, CA 19.9 and alfafetoprotein were normal, and CA 125 was mildly elevated. Abdominal ultrasonography revealed vascular image in the liver hilum with suspicion of aneurysm, and she was transferred to our service. Contrasted abdominal CT (Day 10) characterized periportal edema, and a giant (43 x $38 \mathrm{~mm}$ ) hepatic artery aneurysm (Figs. 1A and 1B). In preoperative period, she developed sudden circulatory shock and cardiorespiratory arrest. Resuscitation measures were unsuccessful, and death occurred on day 12. Necropsy revealed hemoperitoneum (Fig. 1C) due to spontaneous rupture of the hepatic artery aneurysm as immediate cause of death. Grossly, the liver showed yellowish well-delimited softened areas, and the histopathology revealed centrilobular necrosis with no inflammation (Fig. 1D and 1E). 


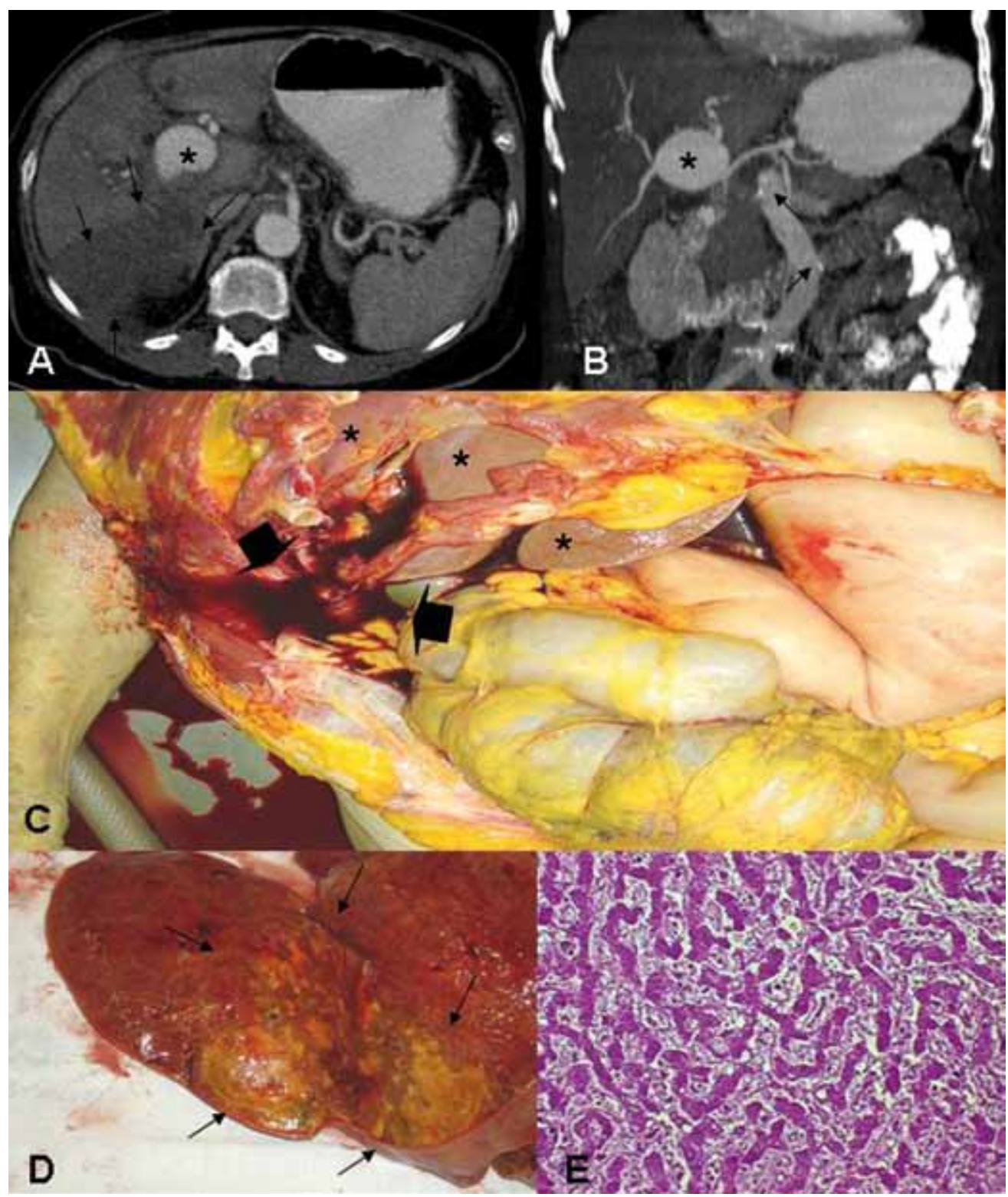

Figure 1A. Axial CT showing conspicuous hepatic artery aneurysm (asterisk) with huge area of liver infarction (arrows).

Figure 1B. Coronal CT showing the hepatic artery aneurysm (asterisk) measuring $43 \mathrm{x} 38 \mathrm{~mm}$, and aortic atherosclerotic plaques (arrows).

Figure 1C. Open abdominal cavity during necropsy, disclosing moderate hemoperitoneum (broad arrows) near to the liver (asterisks), with origin in the ruptured hepatic artery aneurysm.

Figure 1D. Liver surface, showing a yellowish and well-delimited softened area (arrows).

Figure 1E. Hepatic centrilobular necrosis, without inflammatory changes (HE x100). 
The extensive areas of liver ischemic necrosis were associated with huge hepatic arterial thromboembolism (Fig. 2). Severe atherosclerosis was the unique confirmed etiology of the giant hepatic artery aneurysm in this Brazilian female.

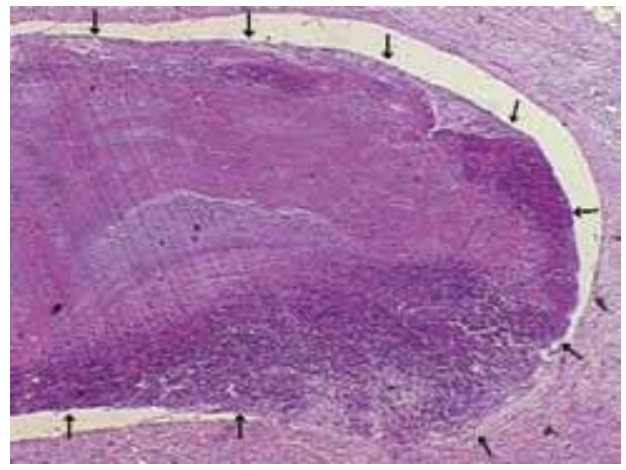

Figure 2. High power feature of a huge thrombus into hepatic artery lumen (arrows).

\section{DISCUSSION}

In the present case, one must emphasize the unnoticed growing of a giant hepatic artery aneurysm, the unspecific clinical manifestations at admission, and the occurrence of ischemic hepatitis. Suspicion of aneurysm arose during imaging studies to clear the origin of jaundice and abdominal pain, because CT images revealed changes in the liver and in the hilar vessels, in addition to aortic atherosclerosis ${ }^{1-3,5}$. Extensive liver infarction like was found in this patient is unusual, due to hepatic dual blood supply. Open surgery, transcatheter coil embolization, endovascular stent-graft, and percutaneous stenting constitute options to treat hepatic artery aneurysms ${ }^{1-3,5,6}$. After diagnosis confirmation by imaging studies, the patient was being prepared to open surgery when spontaneous rupture of the aneurysm caused her death. Necropsy study confirmed the rupture of atherosclerotic aneurysm in common hepatic artery with voluminous hemoperitoneum and liver centrilobular necrosis, without inflammatory changes. Although arterial hypertension could play a role in the present case, the patient was under adequate con- trol, and no remarkable damage was found in the target organs.

Surgical and interventional therapy are usually life-saving procedures for patients with visceral artery aneurysms ${ }^{1,3}$, however, the outcome of these treatments has been variable $^{1-3,5}$. Grotemeyer and colleagues described follow-up data of 23 patients with mean age 55.8 years ( $52.1 \%$ male), submitted to surgical or interventional therapy for visceral artery aneurysms from 1991 to 2006 . The main etiology was atherosclerosis $(67.8 \%)$, nine patients (39.1\%) had no symptoms, and rupture of the aneurysm occurred in four cases (17.3\%). Open surgery was performed in $91.3 \%$ of the patients, and no deaths were observed during the surveillance ${ }^{3}$. Cases-Baldo and colleagues reported unsuccessful surgical treatment for ruptured hepatic artery aneurysm in a 62 year-old male with arterial hypertension. The patient presented with abdominal pain and nausea, followed by sudoresis and syncope heralding the voluminous hemoperitoneum that caused his death $^{2}$. Puppo and colleagues also described unsuccessful surgical management of a large aneurysm detected in the hepatic artery, which caused painless obstructive jaundice in a 47-year-old male with arterial hypertension. The post-operatory complications included liver necrosis and circulatory shock, causing death ${ }^{5}$.

The giant aneurysm was associated with classical features of ischemic hepatitis, which is characterized by centrilobular necrosis and absence of inflammation ${ }^{7-10}$. This uncommon condition is heralded by (over than 20 times the normal range) elevation of transaminases, which is reversible after 24-72 hours and persists for 3-11 days $^{7-10}$. Prolonged prothrombin time, high levels of LDH, GGT, alkaline phosphatase, and bilirubin, in addition to renal dysfunction and glucose changes may be also observed $^{7-10}$.

The aneurysm developed unnoticed during time enough to become giant; fact that can contribute to compressive and ischemic regional disturbances. Unequivocal image of severe obstruction in the portal 
vein flux were not obtained. However, laboratory data were typical of ischemic/ hypoxic hepatitis, and histopathology study characterized hepatic centrilobular necrosis without inflammation ${ }^{7-10}$. In addition to the conspicuous hepatic artery thromboembolism, mechanisms for ischemic/ hypoxic hepatitis in this patient could have included passive congestion secondary to portal vein compression by the giant aneurysm. Furthermore, the aneurysm rupture led to hemorrhagic shock and severe hypoxemia, which made worse the hepatic cell necrosis.

Primary care workers should be aware about the hypothesis of ruptured visceral aneurysms. Although rarely diagnosed in general daily practice, these ominous entities must be included among possible causes of abdominal pain, jaundice, hemoperitoneum, and digestive hemorrhage episodes. Guided by clinical suspicion, imaging studies might be performed as early as possible, to confirm this challenging diagnosis.

\section{REFERENCES}

1. Bellmunt-Montoya S, Maeso-Lebrún J, RoyoSerrando J, Bonfill-Brosa R, Allegue-Allegue N, Matas-Docampo M. Aneurismas de la arteria hepática. Descripción de cinco casos y revisión de la literatura. Angiología 2001; 53: 33-41.

2. Cases-Baldó MJ, Gulllen-Paredes MP, MorenoEgea A, Torres-Del río S, Aguayo-Albasini JL.
Rotura aneurismática de la arteria hepática común. Cir Esp 2010; 87: 51-53.

3. Grotemeyer D, Duran M, Park EJ, Hoffmann N, BLondin D, ISKANDAR F et al. Visceral artery aneurysms-follow-up of 23 patients with 31 aneurysms after surgical or interventional therapy. Langenbecks Arch Surg 2009; 394: 1093-1100.

4. Kim JH, Rha SE, Chun HJ, Kim YS, OH SN, LeE YJ et al. Giant aneurysm of the common hepatic artery: US and CT imaging findings. Abdom Imaging 2010; 35: 212-214.

5. Puppo AM, Pareja F, Muñoz J, Forastero A, BerNARDOS A. Aneurisma de la arteria hepática. Cir Esp 2007; 81: 348-350.

6. Aburano H, Morinaga K, Shigenari N, Inoue D, OKuda M, Minami T et al. Common hepatic artery aneurysm treated with an endovascular stent-graft: a case report. Abdom Imaging 2010;35: 215-217.

7. Fuhrmann V, Jäger B, ZubKova A, Drolz A. Hypoxic hepatitis-epidemiology, pathophysiology and clinical management. Wien Klin Wochenschr 2010; 122: 129-139.

8. Henrion J, Schapira M, Luwaert R, Colin L, DelanNOY A, HELler FR. Hypoxic hepatitis: clinical and hemodynamic study in 142 consecutive cases. Medicine 2003; 82: 392-406.

9. Labega R, Muniesa M, Urbiola E, Jiménez Bermejo F, URDÁNOZ C. Hepatitis isquémica en paciente de 81 años con transposición congénita de grandes vasos. An Sist Sanit Navar 2005; 28 : 261-265.

10. Squella F, Zapata R. Hepatitis isquémica. Caso clínico. Rev Med Chil 2003; 131: 659-664. 
